\title{
GROSS DIET COMPOSITION AND TROPHIC LEVEL ESTIMATION OF THE SPOTCHEEK EMPEROR, LETHRINUS RUBRIOPERCULATUS (ACTINOPTERYGII: PERCIFORMES: LETHRINIDAE), IN THE COMMONWEALTH OF THE NORTHERN MARIANA ISLANDS, MICRONESIA
}

\author{
Michael S. TRIANNI ${ }^{1,2^{*}}$ and Michael C. TENORIO ${ }^{1}$ \\ ${ }^{1}$ Commonwealth of the Northern Mariana Islands Division of Fish and Wildlife, Saipan MP, \\ Northern Mariana Islands \\ ${ }^{2}$ (present affiliation) National Marine Fisheries Service Pacific Islands Fisheries Science Center, Saipan, MP, \\ Northern Mariana Islands
}

Trianni M.S., Tenorio M.C. 2012. Gross diet composition and trophic level estimation of the spotcheek emperor, Lethrinus rubrioperculatus (Actinopterygii: Perciformes: Lethrinidae), in the Commonwealth of the Northern Mariana Islands, Micronesia. Acta Ichthyol. Piscat. 42 (2): 89-99.

Background. The spotcheek emperor, Lethrinus rubrioperculatus Sato 1978, is an important component of the mesophotoic coral reef community in the Indo-Pacific Region, where it is a target of commercial fisheries. A diet composition study was undertaken as part of a broader investigation towards elucidation of the biological characteristics of this species in the Commonwealth of the Northern Mariana Islands, Micronesia..

Materials and methods. A total of 395 spotcheek emperor stomachs were examined between September 2000 and February 2002 based on a commercial fishery and research cruises. Feeding activity was estimated using indices of vacuity and repletion, diet composition was defined using the Main Food Item (MFI) index, and trophic level was determined using Trophlab. All indices were calculated to observe for patterns demographically, seasonally, ontogenetically and by sex.

Results. Total vacuity index $\left(V_{I}\right)$ for fish was $45.8 \%$ while inclusion of bait in stomach (BIS) raised $V_{I}$ to $60.5 \%$. The highest $V_{I}$ came from Farallon de Medinilla, with $63 \%$ and $73 \%$ including BIS. Lowest $V_{I}$ was at Marpi Reef, while Sonome Reef had the largest separation between $V_{I}$ and $V_{I}$ BIS. Repletion indices were greatest in Saipan and Tinian, lowest at Sonome Reef. First quarter year had the highest vacuity and lowest repletion. Repletion increased from the first to fourth quarter while $V_{I}$ did not reveal a pattern. Repletion decreased with size, and $V_{I}$ was highest in the smallest size group. Repletion and $V_{I}$ values were greater in females. MFI results showed fish were the primary prey item at all locations, seasons, and sizes, and in both sexes. Fish increased in diet seasonally. The smallest size group had the highest fish MFI, and the largest size group the lowest. Crustaceans and mollusks were secondary prey items varying by location, season and size. Saipan and Tinian uniquely displayed five prey categories. Overall trophic values were estimated at $4.23 \pm 0.73$, with a range from 3.96 to 4.46 as estimated by location, season size and sex.

Conclusion. Results differed from New Caledonia that reported fish as a secondary food item to crustaceans for spotcheek emperor. In this study mollusks then crustaceans were present as accessory prey items. Demography, ontogeny, and size influenced diet. Estimated trophic levels were indicative of a piscivorous diet, in contrast to the value provided by FishBase. Future work in elucidating observed trends in diet preference for the spotcheek emperor should focus on obtaining a much larger sample size that is more evenly distributed across location, season, size class and sex.

Keywords: Lethrinus rubrioperculatus, diet composition, Northern Mariana Islands, trophic level

\section{INTRODUCTION}

The emperors of the family Lethrinidae comprise a wide range of benthic feeders in coral reef associated tropical and subtropical habitats (Carpenter and Allen 1989). They are noted for their consumption of a variety of macroinvertebrates and nekton (Kulbicki et al. 2005,
Froese and Pauly 2012). Galbo et al. (2002) identified three trophic categories in the genus Lethrinus related to body form and dentition.

A common reef-associated fish of the mesophotic coral reef community in the Indo-Pacific Region, the spotcheek emperor, Lethrinus rubrioperculatus Sato 1978, is a pro-

\footnotetext{
* Correspondence: Michael S. Trianni, National Marine Fisheries Service Pacific Islands Fisheries Science Center, Saipan, MP 96950 Northern Mariana Islands, phone: + 1 670-285-0014, e-mail: mtrianni@ymail.com
} 
togynous hermaphrodite that exhibits a depth distribution from 12-160 m (Froese and Pauly 2012). It represents a significant component of landings in many countries and island jurisdictions (Carpenter and Allen 1989, Dalzell et al. 1996), where it is typically taken in depths from 30-100 m (Ebisawa 1997, Hanoomanjee and Soondron 1999, Trianni 2011). The spotcheek emperor is a mesocarnivore stalker with a low body form and conical teeth that feeds on relatively high-speed prey such as fishes and crustaceans (Galbo et al. 2001). It is often found in large schools and tends to favor hard bottoms under oceanic influences (Kulbicki et al. 2005) such as reef slopes and offshore banks and reefs (Ebisawa 1997, Hanoomanjee and Soondron 1999, Trianni 2011).

The Commonwealth of the Northern Mariana Islands (CNMI) is a Commonwealth of the United States located in northern Micronesia and stretching from the island of Rota in the south to Uracas in the north, that together with the US Territory of Guam form the Mariana Island Archipelago. In the CNMI, the spotcheek emperor comprises a significant portion of coral reef fish landings from populated southern islands of the CNMI including Tinian and Saipan north to Sonome Reef, and is often presented at local cultural events such as fiestas and weddings. Due to its importance as both a food and cultural resource in the CNMI, the CNMI Division of Fish and Wildlife (DFW) commenced a multi-year study on the spotcheek emperor from 1999 through 2002, where data on spotcheek emperor diet composition were collected from a subset of the larger research project. This paper summarizes the findings of diet composition and estimates trophic level for the spotcheek emperor in the CNMI.

\section{METHODS}

The stomach contents of 395 spotcheek emperors landed between September 2000 and February 2002 were evaluated by staff from the CNMI DFW from five locations in the southern islands of the CNMI; Sonome Reef, Farallon de Medinilla (FDM), Marpi Reef, Saipan and Tinian (Fig. 1). These study locations can be subdivided demographically between the populated southern islands of Saipan and Tinian (Anonymous 2011), and north of Saipan two reefs (Marpi and Sonome) and plus an unpopulated tiny island (FDM) that is surrounded by the largest bank in the Marianas Archipelago (Trianni 2011). Typical anthropogenic influences are associated with Tinian and Saipan, including close access to fishing grounds, whereas FDM is used as a target area for US Department of Defense (DoD) training activities. Marpi receives more fishing pressure than FDM and Sonome Reef (CNMI Division of Fish and Wildlife unpublished).

Specimens were collected from the landings of commercial fishing vessels or DFW research cruises as part of a broader life history and evaluation program (Trianni 2011). Stomachs of fresh or thawed frozen fish were excised during life history processing, opened with scissors or dissection scalpels, and the wet contents removed by gentle scraping of interior stomach wall onto a glass petri dish.

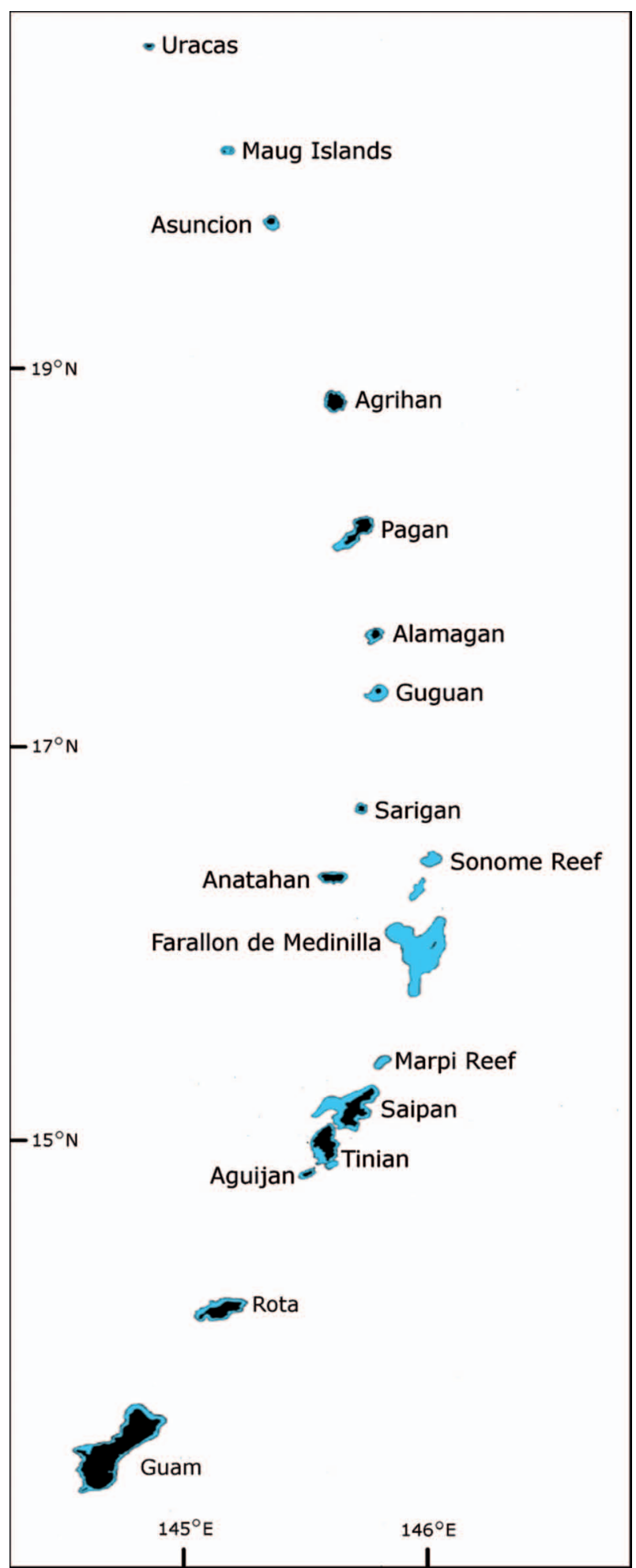

Fig. 1. The Mariana Archipelago, Northern Micronesia, showing the US Territory of Guam and the US Commonwealth of the Northern Mariana Islands

Fish were measured to the nearest $0.1 \mathrm{~cm}$ fork length (FL), then converted to total length (TL) for analysis using a conversion factor from FishBase (Froese and Pauly 2012). Observation and differentiation of stomach contents followed the guidance of Hyslop (1980). Stomach contents were observed under a dissecting 
microscope and diet items differentiated and identified into the lowest possible taxonomic level based upon specimen condition and identifying characteristics. Differentiated stomach contents were then weighed to the nearest $0.01 \mathrm{~g}$ using a top-loading weight scale. Items that were not identifiable were weighed and provided with a numerical count of ' 1 '. Specimen parts were counted as individuals if it was possible to differentiate a particular part from a larger number of parts or an organism. If not, the entire collection of parts, for example fish bones or crustacean shells, was counted as a single organism.

Feeding activity. The vacuity index was calculated as the percentage of empty stomachs, $V_{I}$, as well as the percentage of empty stomachs plus stomachs with only bait, (BIS = bait in stomach). Two variations of the repletion index were also calculated:

$$
R_{W}=100 \times W_{s} \times W_{f}^{-1}(\operatorname{Berg} 1979),
$$

$R_{L}=100 \times W_{S} \times \mathrm{TL}^{-1}$ (Roux and Conand 2000), where: $R_{W}=$ repletion by weight; $R_{L}=$ repletion by length; $W_{s}=$ weight of stomach contents $[\mathrm{g}] ; W_{f}=$ weight of fish $[\mathrm{g}]$; $\mathrm{TL}=$ total length of fish [mm].

Repletion and vacuity indices were evaluated by location, season, size range, and sex. Location consisted of the islands of Tinian, Saipan, Marpi Reef, FDM, and Sonome reefs. Season was divided into four quarters following the format developed by Kikkawa (unpublished*) for the Mariana Islands: Q1 - first quarter (January-March) dry conditions with steady northeasterly trade winds; Q2 - second quarter (April-June) dry with relatively quiet winds; Q3 - third quarter (July-September) winds remain light with higher probability of rainfall and increased chance of typhoon events; and Q4-fourth quarter (October-December) trade winds return with heavy rainfall and potential for severe storm activity. Four size ranges were chosen to evaluate potential ontogenetic shifts in diet: $\mathrm{S}=$ 17.0-21.9 cm TL, converted from FL using conversion factor from FishBase (Froese and Pauly 2011); $\mathrm{M}=22.0-26.9$ cm TL; L = 27.0-31.9 cm TL; and XL > $32.0 \mathrm{~cm}$ TL. Sex was determined by macroscopic evaluation of gonads with undetermined individuals deleted from analysis.

Diet. Diet was evaluated by summarizing calculating three indices:

Percent numerical abundance:

$$
N_{i}=100 \times n_{i} \times N_{p}^{-1}
$$

where: $n_{i}=$ number of individuals of item $i ; N_{p}=$ total number of prey.

Percent total weight:

$$
W_{i}=100 \times w_{i} \times W_{p}^{-1},
$$

where: $w_{i}=$ weight of item $i ; W_{p}=$ total weight of prey.

Percent frequency occurrence;

$$
F_{i}=100 \times S_{i} \times n_{n}{ }^{-1},
$$

where: $S_{i}=$ number of stomachs containing item $i ; n_{n}=$ number of non empty stomachs examined.

These indices were then used to determine the Main Food Item index (MFI) (Zander 1982):

$$
\mathrm{MFI}=\sqrt{\frac{N_{i}+F_{i}}{2} \times W_{i}}
$$

The MFI was evaluated by season, location, size range and sex. Each prey item was then expressed as the cumulated ratio of the total MFI, and graphically evaluated using the following classification: Main prey MFI $\leq 50 \%$, secondary prey $50 \%<$ MFI $<75 \%$ accessory prey MFI $>75 \%$. Instances where an item was identified but not weighed due to extent of digestion were excluded from repletion and MFI analysis. For three fish sex was not determinable.

Trophic level. The trophic level of the spotcheek emperor was determined from diet composition using the program Trophlab, developed by Pauly et al. (2000) and available for download on FishBase (Froese and Pauly 2012). Trophlab estimates the trophic level (TROPH) with standard error (SE) of a fish by consideration of diet composition and the TROPH of prey items, using the fraction of prey items, by volume or weight, in a predator's diet plus one (Pauly et al. 2000). Trophlab provides three degrees of prey taxonomic resolution and identification of a prey life history stage. Trophlab expresses TROPH as:

$$
\underset{j=1}{\mathrm{TROPH} i}=1+\sum_{j=1}^{G} \text { DC } i j \cdot \mathrm{TROPH} j
$$

where $\mathrm{DC}_{i j}$ is the fraction of prey $j$ in the diet of consumer $i$, $\mathrm{TROPH}_{j}$ is the trophic level of $j$, while $G$ is the number of prey categories. TROPH values range from 2.0 for herbivores/detritivores, to 5.0 for piscivorous/carnivorous animals, although 5.0 is rare for even large fish such as sharks (Pauly et al. 1998, Cortés 1999). TROPH values were determined by location, season, size, and sex.

\section{RESULTS}

A total of 395 spotcheek emperor stomachs were evaluated during the sample period. About $6 \%$ of the dietary items assessed, by weight, were not identifiable to a taxonomic group.

Feeding activity. Summary statistics for spotcheek emperor prey categories are listed in Table 1. A total of 224 prey items were enumerated, with fish being dominant by the percentage of weight (74\%) and the frequency of occurrence (31.4\%). The majority of the identifiable fish were muranids, while the overall composition of prey indicated a variety of feeding activity comprised of both sedentary and roaming nekton and zoobenthos. The total $V_{I}$ for the spotcheek emperor was $45.8 \%$ while inclusion of BIS raised vacuity to $60.5 \%$. One fish had swallowed the bait and fish hook.

By location, the highest $V_{I}$ came from FDM, with $63.2 \%$ (73.5\% including BIS) (Table 2). The lowest $V_{I}$ was from Marpi Reef, 20\% (33.3\% with BIS), which also had the smallest number of stomachs sampled. Sonome Reef had a $V_{I}$ of $28.3 \%$ (68.3\% with BIS), the largest discrepancy between $V_{I}$ and $V_{I}$ BIS. Saipan and Tinian had similar indices of vacuity with $45.4 \%$ (57.2\% with BIS) and $49 \%$ (56\% with BIS). Location dependent repletion rates were highest in Saipan and Tinian by both length and weight, lowest at Sonome Reef and Marpi Reef, and median at FDM (Table 3). The largest spotcheek emperors examined were from FDM, Sonome Reef and Marpi

\footnotetext{
* Kikkawa B.S. 1997. WPacFIN Island data assessment (WIDA) of Commonwealth of the Northern Mariana Islands small boat fishery survey, 1988-1993. Southwest Fisheries Science Center Administrative Report H-97-04.
} 
Reef, all north of Saipan, which along with Tinian had distinctly smaller mean sizes, but equitable length ranges in comparison to the other three locations.

For season the first quarter (Q1) had the highest $V_{I}$ $(46.6 \%, 65.7 \%$ with BIS) and the lowest repletion rates (Table 3). Whereas repletion generally increased from the first to fourth quarter, $V_{I}$ did not reveal any pattern, although with the inclusion of BIS the first two quarters vacuity were greater than the last two. Average size of examined fish was lowest in the first and fourth quarters.

Vacuity was highest in the smallest size group at $65.4 \%$ (69.2\% with BIS), and did not vary much between the other size classes although when BIS was added the largest size class increased from a $V_{I}$ of $46.5 \%$ to $65.1 \% V_{I}$
BIS (Table 4). Repletion decreased with size class as the smallest size class uniquely displayed repletion by weight greater than repletion by length. The largest size class had repletion by length less than half, and repletion by weight less than four times that of the smallest size class.

Females had slightly higher repletion values than males, and greater vacuity, $47.6 \%(62.6 \%$ with BIS $)$ to $39.8 \%$ (54.3\% with BIS) (Table 5).

Diet evaluation. The results of MFI calculation are shown in Figs. 2-5. Fish were the primary prey item at all locations. Crustaceans were secondary prey items at Marpi Reef and to a lesser extent at Sonome Reef. Mollusks were secondary prey items at Saipan and FDM, and crustaceans were the only accessory prey item at FDM. Saipan and

Table 1

Prey categories of Lethrinus rubrioperculatus stomachs from the Commonwealth of the Northern Mariana Islands

\begin{tabular}{|c|c|c|c|c|c|c|}
\hline \multirow{2}{*}{ Prey category } & \multicolumn{6}{|c|}{ Parameter } \\
\hline & $N$ & $W_{t}[\mathrm{~g}]$ & $W_{t}[\%]$ & $n$ & Freq. [\%] & $W_{s}[\mathrm{~g}]$ \\
\hline Teleostei & 138 & 132.29 & 74.08 & 124 & 31.4 & 0.335 \\
\hline Unidentified & 107 & 97.26 & 54.46 & 100 & 25.3 & 0.246 \\
\hline Muraenidae & 11 & 10.09 & 5.65 & 9 & 2.3 & 0.026 \\
\hline Balistidae & 5 & 4.32 & 2.42 & 5 & 1.3 & 0.011 \\
\hline Lutjanidae & 2 & 5.21 & 2.92 & 2 & 0.5 & 0.013 \\
\hline Ptereleotridae & 9 & 4.74 & 2.65 & 4 & 1.0 & 0.012 \\
\hline Malacanthidae (Hoplolatilus sp.) & 1 & 7.94 & 4.45 & 1 & 0.3 & 0.020 \\
\hline Acanthuridae (Acanthurus lineatus) & 1 & 1.19 & 0.67 & 1 & 0.3 & 0.003 \\
\hline Scorpaenidae & 1 & 1.09 & 0.61 & 1 & 0.3 & 0.003 \\
\hline Ostraciidae & 1 & 0.45 & 0.25 & 1 & 0.3 & 0.001 \\
\hline Mollusca & 20 & 17.67 & 9.89 & 18 & 4.6 & 0.045 \\
\hline Cephalopoda & 3 & 1.2 & 0.67 & 3 & 0.8 & 0.003 \\
\hline Chitonidae & 1 & 0.57 & 0.32 & 1 & 0.3 & 0.001 \\
\hline Gastropoda & 2 & 0.1 & 0.06 & 2 & 0.5 & 0.000 \\
\hline Nudibranchia & 1 & 0.33 & 0.18 & 1 & 0.3 & 0.001 \\
\hline Octopodidae & 11 & 12.57 & 7.04 & 9 & 2.3 & 0.032 \\
\hline Teuthida & 2 & 2.9 & 1.62 & 2 & 0.5 & 0.007 \\
\hline Crustacea & 28 & 7.78 & 4.36 & 25 & 6.3 & 0.020 \\
\hline Unidentified & 14 & 3.72 & 2.08 & 14 & 3.5 & 0.009 \\
\hline Caridea & 6 & 2.09 & 1.17 & 3 & 0.8 & 0.005 \\
\hline Decapoda & 8 & 1.97 & 1.10 & 8 & 2.0 & 0.005 \\
\hline Echinodermata & 8 & 1.92 & 1.08 & 8 & 2.0 & 0.005 \\
\hline Unidentified & 1 & 0.1 & 0.06 & 1 & 0.3 & 0.000 \\
\hline Ophiocomidae & 2 & 0.07 & 0.04 & 2 & 0.5 & 0.000 \\
\hline Diadematidae & 4 & 1.48 & 0.83 & 4 & 1.0 & 0.004 \\
\hline Holothuridae & 1 & 0.27 & 0.15 & 1 & 0.3 & 0.001 \\
\hline Annelida & 9 & 5.96 & 3.34 & 9 & 2.3 & 0.015 \\
\hline Unidentified & 5 & 2.66 & 1.49 & 5 & 1.3 & 0.007 \\
\hline Polychaeta & 3 & 1.56 & 0.87 & 3 & 0.8 & 0.004 \\
\hline Sipuncula & 1 & 1.74 & 0.97 & 1 & 0.3 & 0.004 \\
\hline Salpidae & 1 & 1.01 & 0.57 & 1 & 0.3 & 0.003 \\
\hline Unidentified eggs & 19 & 10.4 & 5.82 & 19 & 4.8 & 0.026 \\
\hline Unidentified & 1 & 1.55 & 0.87 & 1 & 0.3 & 0.004 \\
\hline Total & 224 & 178.58 & 100.00 & & & 0.452 \\
\hline
\end{tabular}

$N=$ number of counts; $W_{t}=$ total weight; $W_{t} \%=$ percentage weight; $n=$ number of stomachs containing respective prey category; Freq. $=$ frequency of occurrence; $W_{s}=$ weight per stomach sampled. 
Tinian each showed the presence of five prey categories evaluated, most notably the presence of annelids, which were absent from the other locations (Fig. 2). Fish became a larger part of diet over the course of a year, becoming a dominant prey item during period Q3 (July-September) increasing in dominance during period Q4 (October-December) resulting in over 90\% MFI for fish (Fig. 3). Mollusks were secondary prey items during the first two periods. The smallest size group (small, S) (Fig. 4,) presented over $90 \%$ MFI for fish (77\% of fish from Saipan and Tinian), with the largest size group (XL) recording the lowest MFI for fish (77\% of fish from north of Saipan). Mollusks were secondary prey items for size group M and L, where fish did not exceed $75 \%$ MFI. Males recorded a fish MFI value over $75 \%$, and females a value over $71 \%$ with mollusks as a secondary prey item (Fig. 5).

Trophic level. The overall TROPH for the spotcheek emperor was estimated at 4.23 with a standard error (SE) of 0.73. The largest TROPH ( \pm standard error) level was recorded at $4.46 \pm 0.79$ from size class $\mathrm{S}(16-20 \mathrm{~cm} \mathrm{TL})$, and the lowest was $3.96 \pm 0.70$ from Marpi Reef.

\section{DISCUSSION}

Vacuity plus BIS values mostly mirrored vacuity values with the exception being at Sonome Reef, where the addition of BIS made a considerable difference. Sonome Reef was the only location, season, or size range where BIS exceeded $V_{I}$ (Table 2). Coupled with the lowest demographic repletion indices, it would appear that there might be increased competition for prey at Sonome Reef. It is the location furthest from the population center of Saipan, and therefore receives the lowest level of anthropomorphic influence, in the form of fishing pressure. A similar situation may be suggested for FDM which had the highest $V_{I}$ and $V_{I}$ BIS values, given its distance from Saipan and its relative isolation due to U.S. DoD training

Table 2

Percent contribution of prey groups (and other major parameters) of Lethrinus rubrioperculatus from the Commonwealth of the Northern Mariana Islands at individual sites

\begin{tabular}{|c|c|c|c|c|c|}
\hline \multirow{2}{*}{ Prey category or parameter } & \multicolumn{5}{|c|}{ Site (island) } \\
\hline & FDM & Marpi & Saipan & Sonome & Tinian \\
\hline Teleostei & 61.41 & 51.07 & 72.93 & 78.52 & 79.35 \\
\hline Mollusca & - & - & - & - & - \\
\hline Octopodidae & 29.40 & 0.00 & 5.43 & 2.86 & 5.95 \\
\hline Chitonidae & - & 10.14 & - & - & - \\
\hline Nudibranchia & - & - & - & 1.63 & - \\
\hline Gastropoda & - & - & 0.13 & - & - \\
\hline Teuthida & - & - & 3.37 & 1.04 & - \\
\hline Cephalopoda & - & - & 1.51 & - & - \\
\hline Crustacea & 9.19 & - & 1.23 & 7.11 & - \\
\hline Caridea & - & 32.03 & 0.10 & 1.04 & - \\
\hline Decapoda & - & - & 1.66 & - & 1.10 \\
\hline Echinodermata & - & - & - & - & 0.17 \\
\hline Holothuridae & - & - & - & - & 0.46 \\
\hline Diadematidae & - & - & 1.07 & 3.11 & - \\
\hline Ophiocomidae & - & - & - & 0.35 & - \\
\hline Annelida & - & - & 1.86 & 0.99 & 1.67 \\
\hline Polychaeta & - & - & 1.96 & - & - \\
\hline Sipuncula & - & - & 2.18 & - & - \\
\hline Unidentified eggs & - & - & - & - & 2.63 \\
\hline Salpidae & - & - & - & - & 1.72 \\
\hline Unidentified & 0.00 & 6.76 & 6.59 & 3.36 & 6.95 \\
\hline No. of stomachs & 68 & 15 & 152 & 60 & 100 \\
\hline Vacuity index & 63.2 & 20.0 & 45.4 & 28.3 & 49.0 \\
\hline$\%$ Bait & 10.3 & 13.3 & 11.8 & 40.0 & 7.0 \\
\hline Repletion by length & $0.433 \pm 0.074$ & $0.29 \pm 0.08$ & $0.489 \pm 0.073$ & $0.278 \pm 0.057$ & $0.556 \pm 0.087$ \\
\hline Repletion by weight & $0.337 \pm 0.064$ & $0.233 \pm 0.073$ & $0.455 \pm 0.077$ & $0.213 \pm 0.044$ & $0.482 \pm 0.07$ \\
\hline Length range (TL) & $15.0-36.9$ & $25.0-32.6$ & $18.1-34.7$ & $22.5-34.6$ & $18.1-38.8$ \\
\hline Mean length (TL) & 29.1 & 28.9 & 26.6 & 28.9 & 25.9 \\
\hline TROPH & $4.41 \pm 0.70$ & $3.96 \pm 0.70$ & $4.23 \pm 0.72$ & $4.25 \pm 0.74$ & $4.24 \pm 0.74$ \\
\hline
\end{tabular}

FDM $=$ Farallon de Medinilla; values are mean \pm standard error (where applicable); length unit: cm; weight unit: g; TL = total length. 
activities that limit fishing access, although repletion rates were third to Tinian and Saipan (Table 2). Both Saipan and Tinian had lower $V_{I}$ plus $V_{I}$ BIS values, in comparison to Sonome Reef and FDM, as well as the highest repletion rates, indicating differential feeding between the populated and most isolated areas that may be tied to density dependent factors including growth rate, which was found to differ between these two demographic areas (Trianni 2011). Marpi Reef had the lowest $V_{I}$ and $V_{I}$ BIS values and second lowest repletion rate values, but also small sample sizes which may have resulted in an incomplete portrait of diet. There were some differences in demographic MFI values, as all five food groups were only identified in Saipan and Tinian, with the Tinian prey composition strongly favoring fish. There have been numerous studies regarding the impacts of fishing pressure on marine ecosystem food webs (Pauly and Palomares 2000, Polovina et al. 2009, Madin et al. 2010), and further research into vacuity and diet between areas of human population with easy access to fishing grounds, in comparison to areas further distant, may provide elucidation regarding observed patterns in the spotcheek emperor.

Repletion rates increased during the year, being the greatest in the last period, and the reliance on fish as a primary food source increased considerably (Table 3; Fig. 3). Both of these trends were influenced by the samples for that period having been obtained from Tinian, which comprised the fish of season Q4. One sample during season Q3 was obtained from Marpi Reef, but this sample was unlikely to have a strong influence on seasonal prey composition due to the small sample size. Both samples from FDM were obtained in a single season (Q2). A more accurate analysis of seasonal influences would require sampling from each location during each season with similar sample sizes. The difficulty of achieving equitable samples results from the seasonal challenges in accessing Sonome Reef, FDM and even Marpi Reef due to the increased threat of typhoons during season Q4, as well as the rough condi-

Percent contribution of prey groups (and other major parameters) of Lethrinus rubrioperculatus from the Commonwealth of the Northern Mariana Islands at different seasons (quarter of the year)

\begin{tabular}{|c|c|c|c|c|}
\hline \multirow{2}{*}{ Prey category or parameter } & \multicolumn{4}{|c|}{ Season } \\
\hline & Q1 & Q2 & Q3 & $\mathrm{Q} 4$ \\
\hline Teleostei & 61.51 & 74.65 & 74.87 & 88.26 \\
\hline \multicolumn{5}{|l|}{ Mollusca } \\
\hline Octopodidae & 13.99 & 10.84 & - & - \\
\hline Chitonidae & - & - & 1.41 & - \\
\hline Nudibranchia & 0.73 & - & - & - \\
\hline Gastropoda & - & 0.17 & - & - \\
\hline Teuthida & 0.47 & 4.64 & - & - \\
\hline Cephalopoda & - & - & 2.97 & - \\
\hline Crustacea & 0.56 & 2.60 & 4.84 & - \\
\hline Caridea & 0.47 & 0.14 & 4.45 & - \\
\hline Decapoda & 0.22 & 2.10 & - & 1.85 \\
\hline Echinodermata & 0.22 & - & - & - \\
\hline Holothuridae & - & - & - & 0.77 \\
\hline Diadematidae & 2.36 & 0.72 & - & - \\
\hline Ophiocomidae & 0.16 & - & - & - \\
\hline Annelida & 5.41 & - & 0.57 & - \\
\hline Polychaeta & 2.90 & 0.45 & - & - \\
\hline Sipuncula & - & - & 4.30 & - \\
\hline Unidentified eggs & - & - & - & 4.40 \\
\hline Salpidae & - & - & - & 2.87 \\
\hline Unidentified & 11.00 & 3.69 & 6.60 & 1.85 \\
\hline No. of stomachs & 131 & 126 & 75 & 63 \\
\hline Vacuity Index & 46.6 & 50.8 & 33.3 & 49.2 \\
\hline$\%$ Bait & 19.1 & 10.3 & 20.0 & 7.9 \\
\hline Repletion by length & $0.32 \pm 0.044$ & $0.516 \pm 0.098$ & $0.491 \pm 0.079$ & $0.613 \pm 0.140$ \\
\hline Repletion by weight & $0.282 \pm 0.041$ & $0.485 \pm 0.105$ & $0.406 \pm 0.080$ & $0.514 \pm 0.105$ \\
\hline Length range (TL) & $18.1-38.8$ & $18.0-36.9$ & $21.6-34.6$ & $18.1-32.8$ \\
\hline Mean length (TL) & 26.8 & 28.0 & 28.4 & 25.3 \\
\hline TROPH & $4.10 \pm 0.69$ & $4.34 \pm 0.73$ & $4.19 \pm 0.73$ & $4.33 \pm 0.77$ \\
\hline
\end{tabular}

Values are mean \pm standard error (where applicable); Q1 = first quarter; Q2 = second quarter; Q3 = third quarter; Q4 = fourth quarter length unit: $\mathrm{cm}$; weight unit: $\mathrm{g}$; TL = total length. 
tions that arise from the trade wind season, Q1. Therefore results obtained here suggest, but are inconclusive, regarding a seasonal component to prey selection.

The vacuity rate and repletion values were highest in the smallest size class, which uniquely yielded repletion weight values greater than those for length. The high MFI value for fish in the smallest size class may be influential in the repletion weight value as the digestibility of fish may be lower than mollusks or crustaceans. Ontogenetic diet shifts have been observed in a variety of marine fish species (Karpouzi and Stergiou 2003). Kulbicki et al. 2005 found that the diversity of prey items for the spotcheek emperor were relatively equitable over size, although the main prey item, crustaceans, tended to decrease with size while the presence of fish in the diet tended to increase with size. It appears that there is an ontogenetic diet shift for prey selection in the spotcheek emperor in the CNMI as fish MFI tended to decrease with size as mollusks and crustaceans increased in importance, and repletion rates became very low. These results suggest a shift towards a more generalist feeding strategy in the spotcheek emperor in the CNMI as it approaches its asymptotic size.

The spotcheek emperor is a shoaling species (Ebisawa 1997). The cost/benefits of shoaling are complex, and there exists evidence that shoal size increases with body length, although it is not clear if this is a result of active choice or other factors (Hoare et al. 2000). Recent theory suggests that as predation pressure increases, the size of non-patchy feeding shoals will also increase, as a defensive response (Mayer 2010), perhaps increasing the competition for food resources. The smallest size classes were dominated by fish from Saipan and Tinian ( $\mathrm{S}=77 \% ; \mathrm{M}=86 \%$ ), which implies possible demographic differences in prey availability or in predation pressure. It has been noted that areas around populated islands in the CNMI are typically subjected to greater fishing pressure (Richards et al. 2012), and changes in community structure with indirect effects in demographic structure have been observed in coral reef systems (Dulvy et al. 2004, Ruttenberg et al. 2011). A decrease in predation pressure may provide for smaller

Table 4

Percent contribution of prey groups (and other major parameters) of Lethrinus rubrioperculatus from the Commonwealth of the Northern Mariana Islands at different size groups

\begin{tabular}{|c|c|c|c|c|}
\hline \multirow{2}{*}{ Prey category or parameter } & \multicolumn{4}{|c|}{ Size group } \\
\hline & $\mathrm{S}$ & M & $\mathrm{L}$ & XL \\
\hline Teleostei & 94.27 & 64.86 & 81.18 & 64.65 \\
\hline Mollusca & - & - & - & - \\
\hline Octopodidae & 1.43 & 6.84 & 6.22 & 20.51 \\
\hline Chitonidae & - & 0.76 & - & - \\
\hline Nudibranchia & - & 0.44 & - & - \\
\hline Gastropoda & - & - & 0.12 & - \\
\hline Teuthida & - & 3.86 & - & - \\
\hline Cephalopoda & - & 0.61 & 0.89 & - \\
\hline Crustacea & 4.29 & 0.39 & 1.80 & 14.75 \\
\hline Caridea & - & - & 2.51 & - \\
\hline Decapoda & - & 2.21 & 0.37 & - \\
\hline Echinodermata & - & - & 0.12 & - \\
\hline Holothuridae & - & 0.36 & - & - \\
\hline Diadematidae & - & 1.97 & - & - \\
\hline Ophiocomidae & - & - & 0.08 & - \\
\hline Annelida & - & 3.53 & - & 0.10 \\
\hline Polychaeta & - & 0.75 & 1.20 & - \\
\hline Sipuncula & - & 2.32 & - & - \\
\hline Unidentified eggs & - & 2.06 & - & - \\
\hline Salpidae & - & 1.34 & - & - \\
\hline Unidentified & - & 7.72 & 5.51 & - \\
\hline No. of stomachs & 26 & 175 & 151 & 43 \\
\hline Vacuity Index & 65.4 & 49.1 & 38.4 & 46.5 \\
\hline$\%$ Bait & 3.8 & 11.4 & 19.2 & 18.6 \\
\hline Repletion by length & $0.574 \pm 0.282$ & $0.483 \pm 0.067$ & $0.494 \pm 0.059$ & $0.253 \pm 0.196$ \\
\hline Repletion by weight & $0.589 \pm 0.423$ & $0.469 \pm 0.063$ & $0.337 \pm 0.041$ & $0.147 \pm 0.029$ \\
\hline TROPH & $4.46 \pm 0.79$ & $4.11 \pm 0.69$ & $4.32 \pm 0.75$ & $4.33 \pm 0.71$ \\
\hline
\end{tabular}

Values are mean \pm standard error (where applicable); $\mathrm{S}=17.0-21.9 \mathrm{~cm} ; \mathrm{M}=22.0-26.9 \mathrm{~cm} ; \mathrm{L}=27.0-31.9 \mathrm{~cm} ; \mathrm{XL}>32.0$ cm TL; length unit: cm; weight unit: g; TL = total length. 


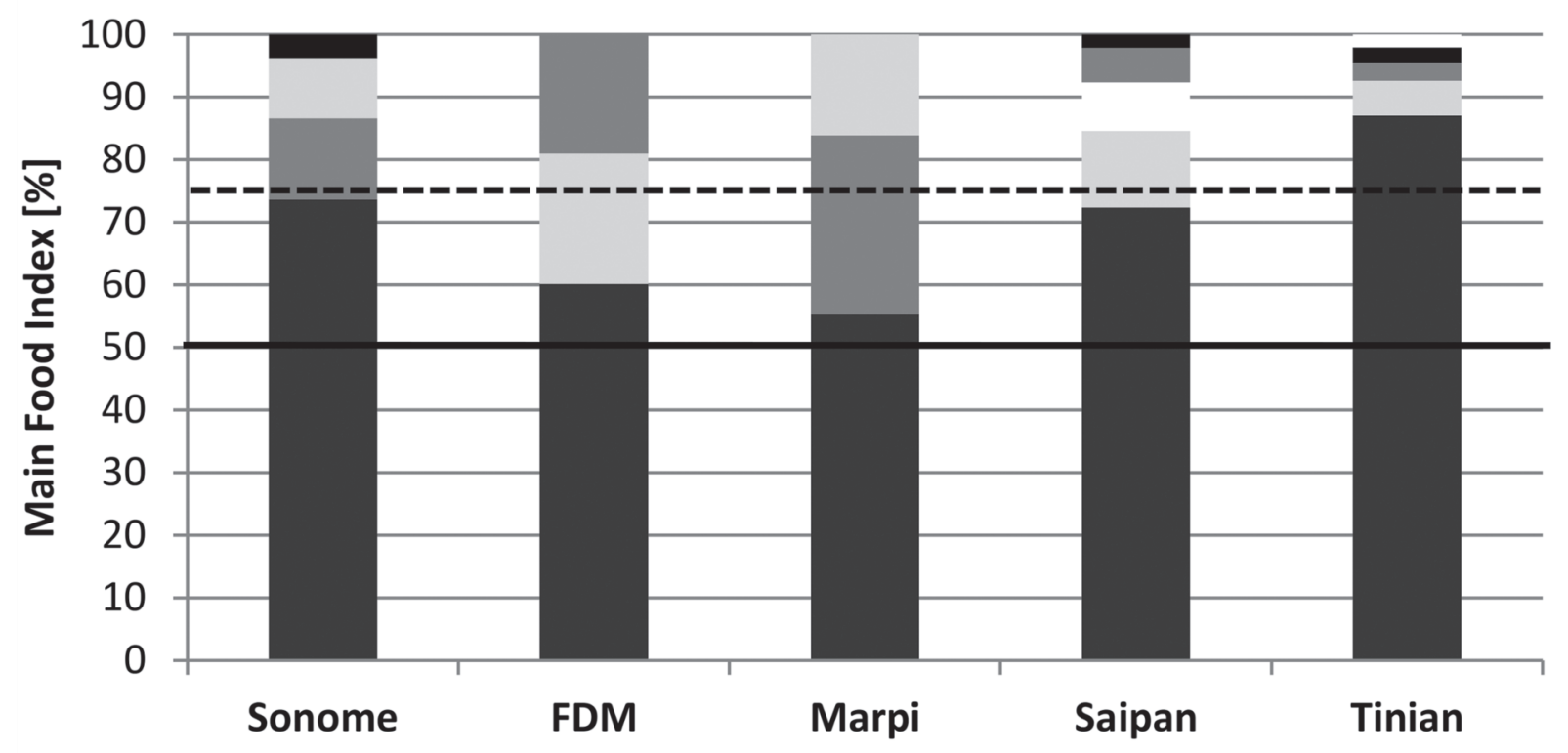

- Teleost Mollusk Crustacean Echinoderm Annelid

Fig. 2. Main Food Index (MFI) of Lethrinus rubrioperculatus from Northern Mariana Islands at different locations; main prey — below solid line; secondary prey_between solid- and dashed lines; accessory prey—above dashed line; FDM = Farallon de Medinilla

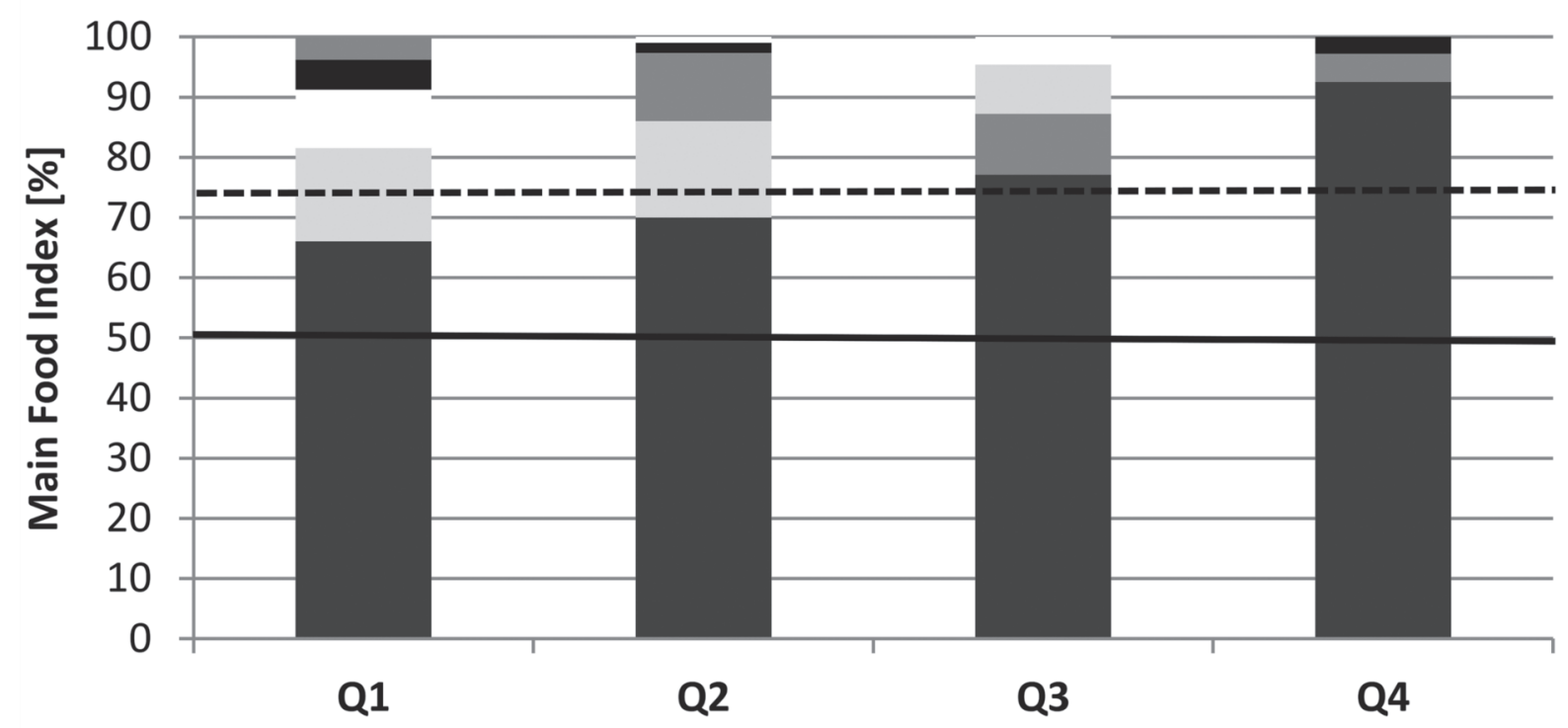

- Teleost Mollusk Annelid Echinoderm $\square$ Crustacean

Fig. 3. Main Food Index (MFI) of Lethrinus rubrioperculatus from Northern Mariana Islands at different quarters of the year; main prey_-below solid line; secondary prey_-between solid- and dashed lines; accessory prey-above dashed line; Q1 = first quarter; Q2 = second quarter; Q3 = third quarter; Q4 = fourth quarter 


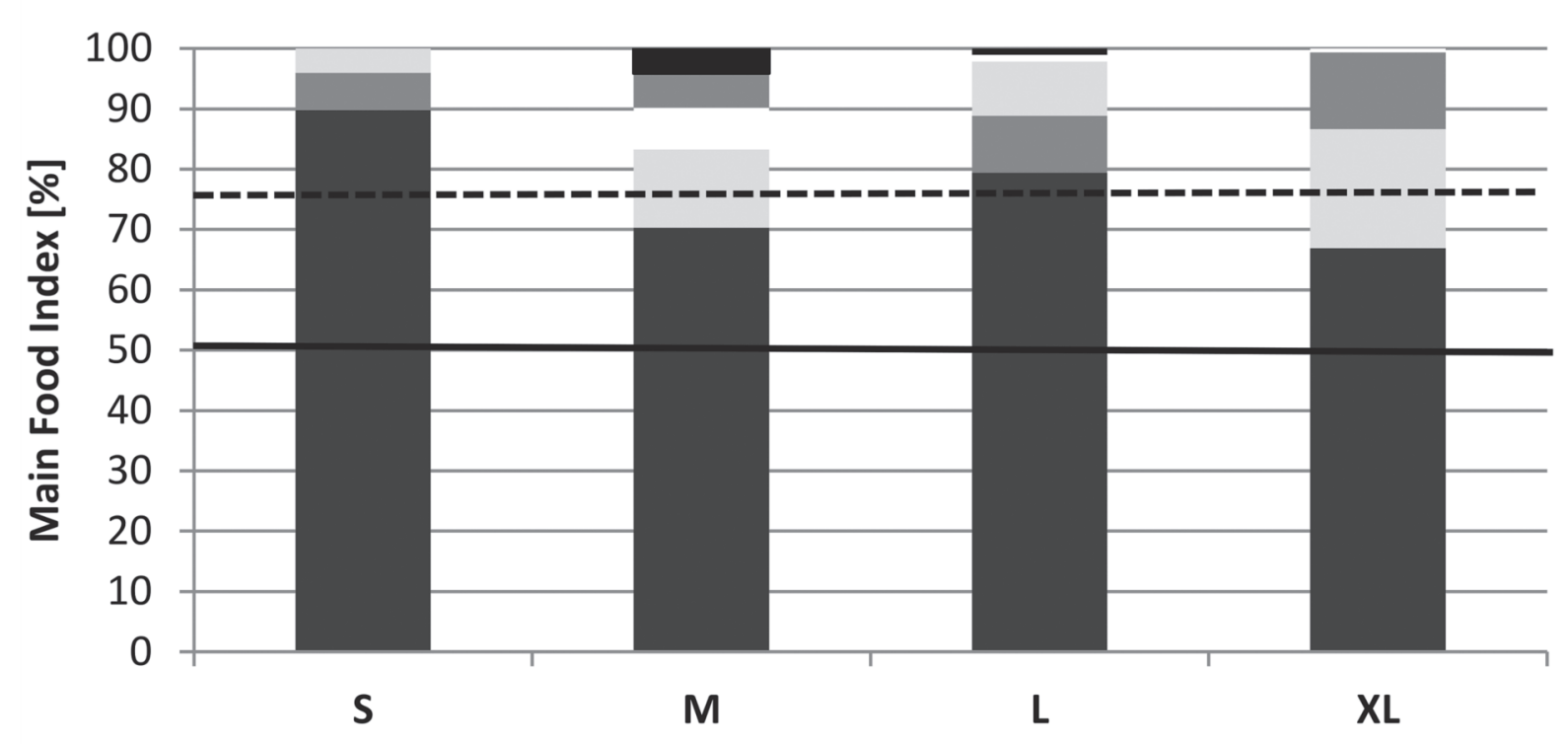

C

- Teleost Crustacean Mollusk Annelid Echinoderm

Fig. 4. Main Food Index (MFI) of Lethrinus rubrioperculatus from Northern Mariana Islands in different size groups; main prey — below solid line; secondary prey_between solid- and dashed lines; accessory prey-above dashed line; $\mathrm{S}=17.0-21.9 \mathrm{~cm} ; \mathrm{M}=22.0-26.9 \mathrm{~cm} ; \mathrm{L}=27.0-31.9 \mathrm{~cm} ; \mathrm{XL}>32.0 \mathrm{~cm}$ TL

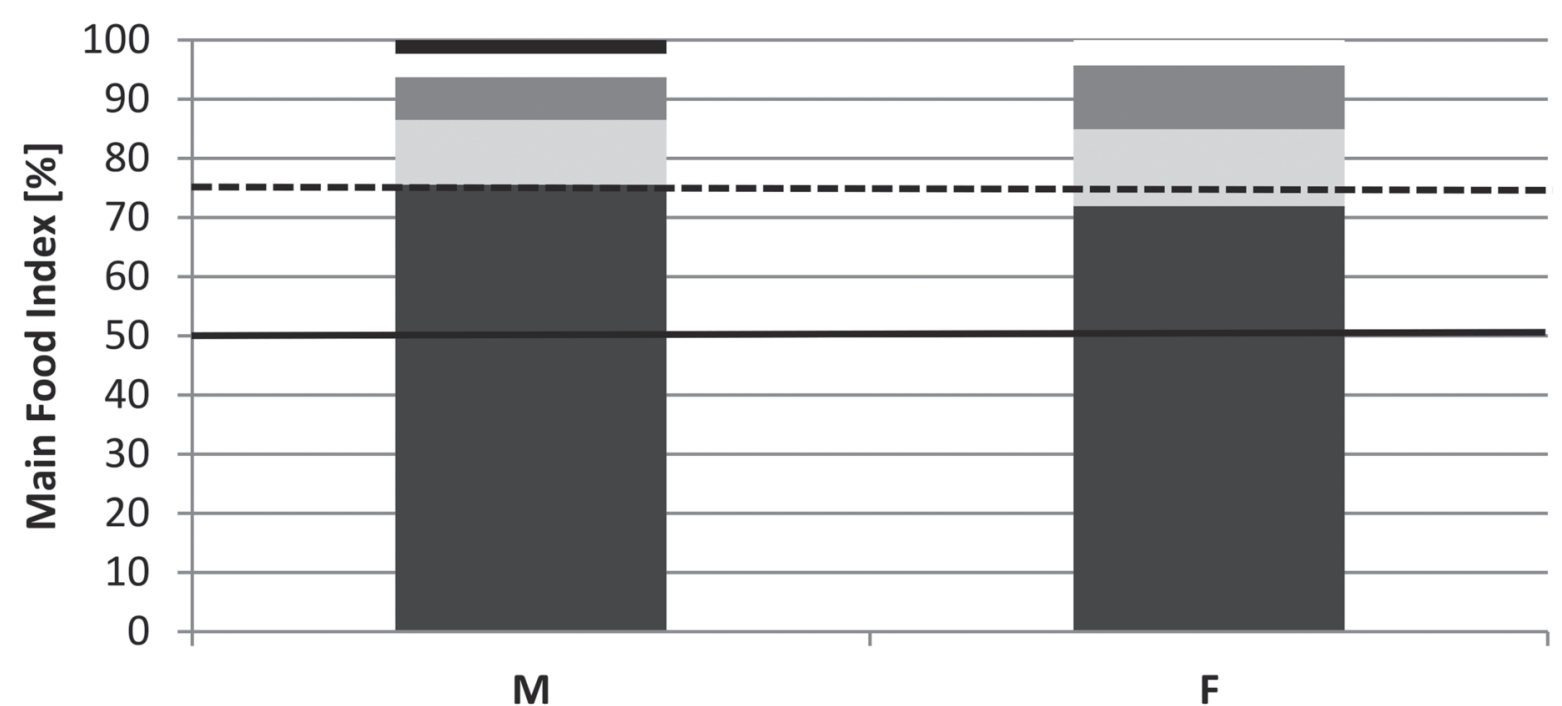

- Teleost Mollusk Crustacean Annelid Echinoderm

Fig. 5. Main Food Index (MFI) of Lethrinus rubrioperculatus from Northern Mariana Islands for both sexes; main prey_-below solid line; secondary prey_-between solid- and dashed lines; accessory prey_above dashed line; $\mathrm{M}=$ male, $\mathrm{F}=$ female 
shoals and a greater opportunity to feed, resulting in higher repletion rates, as observed for Saipan and Tinian.

There were differences in vacuity indices, MFI, and repletion rates between males and females, with vacuity showing the largest difference, while repletion rates and MFI appearing to be insignificant (Fig. 5; Table 5). While ontogenetic diet shifts in hermaphroditic species have been observed in a variety of habitats (Mullaney 1994, Morato et al. 2000, Kallianiotis et al. 2005, Kulbicki et al. 2005, Osman and Mahmoud 2009) it would appear that more work is needed with respect to diet changes when fish are approaching size at maturity in the initial phase and size at transition to the terminal phase.

FishBase (Froese and Pauly 2012) provides a TROPH of 3.6 for the spotcheek emperor based on the work of Kulbicki et al. (2005), which is lower than the overall value of 4.23 obtained during the presently reported

Table 5

Percent contribution of prey groups

(and other major parameters) by sex of Lethrinus rubrioperculatus from the Commonwealth of the Northern Mariana Islands at individual sites

\begin{tabular}{|c|c|c|}
\hline Prey category or parameter & Female & Male \\
\hline Teleostei & 74.42 & 74.22 \\
\hline \multicolumn{3}{|l|}{ Mollusca } \\
\hline Octopodidae & 5.10 & 14.00 \\
\hline Chitonidae & 0.41 & - \\
\hline Nudibranchia & 0.24 & 一 \\
\hline Gastropoda & 0.07 & - \\
\hline Teuthida & 2.11 & - \\
\hline Cephalopoda & 0.87 & - \\
\hline Crustacea & 0.89 & 5.22 \\
\hline Caridea & 1.52 & - \\
\hline Decapoda & 1.22 & 0.73 \\
\hline Echinodermata & 0.07 & - \\
\hline Holothuridae & 0.20 & 一 \\
\hline Diadematidae & 0.77 & 一 \\
\hline Ophiocomidae & 0.05 & 一 \\
\hline Annelida & 1.03 & 3.13 \\
\hline Polychaeta & 0.91 & 0.76 \\
\hline Sipuncula & 1.26 & - \\
\hline Unidentified eggs & 1.13 & 一 \\
\hline Salpidae & 0.73 & - \\
\hline Unidentified & 6.99 & 1.94 \\
\hline No. of stomachs & 307 & 83 \\
\hline Vacuity Index & 47.6 & 39.8 \\
\hline$\%$ Bait & 15.0 & 14.5 \\
\hline Repletion by length & $0.47 \pm 0.058$ & $0.445 \pm 0.027$ \\
\hline Repletion by weight & $0.431 \pm 0.059$ & $0.316 \pm 0.02$ \\
\hline Length range (TL) & $18.0-38.8$ & 21.9-33.8 \\
\hline Mean length (TL) & 26.6 & 30.1 \\
\hline TROPH & $4.22 \pm 0.72$ & $4.34 \pm 0.73$ \\
\hline
\end{tabular}

Values are mean \pm standard error (where applicable); length unit: cm; weight unit: g; TL = total length. study. The primary difference between the two TROPH estimates is the dominance of fish in the CNMI spotcheek diet. Although Kulbicki et al. (2005) reported crustaceans as having a much greater importance in spotcheek diet in New Caledonia, they did note that the spotcheek consumed more fish than other lethrinids. The overall CNMI spotcheek emperor TROPH value approached 4.5 , a value considered to be indicative of a pure piscivore (Pauly et al. 1998, Cortés 1999). The difference between TROPH values from the CNMI and New Caledonia suggests further consideration of TROPH for this species from other locations in the Indo-Pacific, although the range between estimates would certainly fit the description of a mesocarnivore stalker that feeds on relatively high-speed prey such as fishes and crustaceans (Carpenter 1996).

Future work on the diet and trophic position of the spotcheek emperor in the Mariana Archipelago should focus on obtaining equivalent samples from locations, seasons, size ranges and sexes, which would allow for more formal testing of observations documented here. Ideally, the study area would be expanded to the Territory of Guam and its associated reefs as fisheries management regulatory mechanisms, and human demographics differ substantially from the CNMI.

Stergiou and Karpouzi (2001) provided several recommendations to guide future stomach content studies, and having a protocol to follow as such will improve comparability between studies, especially for species whose distributions span oceanic basins like the spotcheek emperor.

\section{ACKNOWLEDGEMENTS}

This study was fully funded by the US DingellJohnson Sportfish Restoration Act grant, as administered by the US Fish and Wildlife Service. The authors thank CNMI Division of Fish and Wildlife personnel for assistance in carrying out research cruises, processing specimens, and aid in identifying stomach contents.

\section{REFERENCES}

Anonymous 2011. U.S. Census Bureau Releases 2010 Census Population Counts for the Northern Mariana Islands. United States Census Bureau

http://2010.census.gov/news/releases/operations/cb11-cn178.html.

Berg J. 1979. Discussion of methods of investigating the food of fishes, with reference to a preliminary study of the prey of Gobiusculus flavescens. Marine Biology 50 (3): 263-273. DOI: $10.1007 / \mathrm{BF} 00394208$

Carpenter K.E. 1996. Morphometric pattern and feeding mode in emperor fishes (Lethrinidae, Perciformes). Pp 479-487. In: Marcus L.F., Corti M., Loy A., Naylor G., Slice D.E. (eds.). Advances in morphometrics. Plenum Press, New York.

Carpenter K.E., Allen G.R. 1989. FAO Species Catalogue. Vol. 9. Emperor fishes and large-eye breams of the world (family Lethrinidae). An annotated and illustrated catalogue of lethrinid species known to date. FAO Species Synopsis No. 125 (9).

Cortés E. 1999. Standardized diet compositions and trophic levels of sharks. ICES Journal of Marine Science 56 (5): 707-717. DOI: $10.1006 /$ jmsc. 1999.0489 
Dalzell P.T., Adams T.J.H., Polunin N.V.C. 1996. Coastal fisheries in the Pacific Islands. Oceanography and Marine Biology: An Annual Review 34: 395-531.

Dulvy N.K., Freckleton R.P., Polunin N.V.C. 2004. Coral reef cascades and the indirect effects of predator removal by exploitation. Ecology Letters 7 (5): 410-416. DOI: $10.1111 /$ j.1461-0248.2004.00593.x

Ebisawa A. 1997. Some aspects of reproduction and sexuality in the spotcheek emperor, Lethrinus rubrioperculatus, in waters off the Ryukyu Islands. Ichthyological Research 44 (3-2): 201-212. DOI: $10.1007 / \mathrm{BF} 02678698$

Froese R., Pauly D. (eds.) 2012. FishBase. [version 02/2012] http://www.fishbase.org.

Galbo A.M.L., Carpenter K.E., Reed D.L. 2002. Evolution of trophic types in emperor fishes (Lethrinus, Letherinidae, Percoidei) based on cytochrome $b$ gene sequence variation. Journal of Molecular Evolution 54 (6): 754-762. DOI: $10.1007 / \mathrm{s} 0023901-0076-\mathrm{z}$

Hanoomanjee S., Soondron V. 1999. An assessment of Lethrinus rubrioperculatus on the Soudan Bank. Pp. 151-158. In: Proceedings, 3rd Annual Meeting, Agricultural Scientists, Reduit, Mauritius, 17-18 November 1998. Food and Agricultural Research Council.

Hoare D.J., Krause J., Peuhkuri N., Godin J.-G.J. 2000. Body size and shoaling in fish Journal of Fish Biology 57 (6): 1351-1366.

DOI: $10.1006 /$ jbi.2000.1446

Hyslop E.J. 1980. Stomach contents analysis—a review of methods and their application. Journal of Fish Biology 17 (4): 411-429. DOI: $10.1111 / \mathrm{j} .1095-8649.1980 . t b 02775 . x$

Kallianiotis A., Torre M., Argyri A. 2005. Age, growth, mortality, reproduction, and feeding habits of the striped seabream, Lithognathus mormyrus (Pisces: Sparidae), in the coastal waters of the Thracian Sea, Greece. Scientia Marina 69 (3): 391-404.

DOI: $10.3989 /$ scimar.2005.69n3391

Karpouzi V.S., Stergiou K.I. 2003. The relationships between mouth size and shape and body length for 18 species of marine fishes and their trophic implications. Journal of Fish Biology 62 (6): 1353-1365.

DOI: $10.1046 / j .1095-8649.2003 .00118 . x$

Kulbicki M., Bozec Y.-M., Labrosse P., Letourneur Y., Mou-Tham G., Wantiez L. 2005. Diet composition of carnivorous fishes from coral reef lagoons of New Caledonia. Aquatic Living Resources 18 (3): 231-250.

DOI: $10.1051 /$ alr:2005029

Madin E.M.P., Gaines S.D., Warner R.R. 2010. Field evidence for pervasive indirect effects of fishing on prey foraging behavior. Ecology 91 (12): 3563-3571.

DOI: $10.1890 / 09-2174.1$

Mayer P.C. 2010. Economic models of fish shoal (school) size: a near comprehensive view of single species shoaling strategy. Journal of Bioeconomics 12 (2): 119-143.

DOI: $10.1007 / \mathrm{s} 10818-010-9084-7$

Morato T., Santos R.S., Andrade J.P. 2000. Feeding habits, seasonal and ontogenetic diet shift of blacktail comber,
Serranus atricauda (Pisces: Serranidae), from the Azores, north-eastern Atlantic. Fisheries Research 49 (1): 51-59. DOI: $10.1016 / \mathrm{S} 0165-7836(00) 00189-2$

Mullaney M.D.jr. 1994. Ontogenetic shifts in diet of gag, Mycteroperca microlepis, (Goodeand Bean), (Pisces: Serranidae). Proceedings of the Gulf and Caribbean Fisheries Institute 43: 432-445.

Osman A., Mahmoud H.H. 2009. Feeding biology of Diplodus sargus and Diplodus vulgaris (Teleostei, Sparidae) in Egyptian Mediterranean waters. World Journal of Fish and Marine Sciences 1: 290-296.

Pauly D., Palomares M.L. 2000 Approaches for dealing with three sources of bias when studying the fishing down marine food web phenomenon. Pp. 61-66. In: Briand F. (ed.) Fishing down the Mediterranean food webs? Vol. 12. CIESM Workshop Series.

Pauly D., Froese R., Sa-a P.S., Palomares M.L., Christensen V., Rius J. 2000. TrophLab Manual. ICLARM, Manila, Philippines.

Pauly D., Trites A.W., Capuli E., Christensen V. 1998. Diet composition and trophic levels of marine mammals. ICES Journal of Marine Science 55 (3): 467-481.

DOI: $10.1006 /$ jmsc. 1997.0280

Polovina J.J., Abecassis M., Howell E.A., Woodworth P. 2009. Increases in the relative abundance of mid-trophic level fishes concurrent with declines in apex predators in the subtropical North Pacific, 1996-2006. Fishery Bulletin 107: 523-531.

Richards B.L., Williams I.D., Vetter O.J., Williams G.J. 2012. Environmental factors affecting large-bodied coral reef fish assemblages in the Mariana Archipelago. PLoS ONE 7 (2): e31374.

DOI: 10.1371 /journal.pone.0031374

Roux O., Conand F. 2000. Feeding habits of the bigeye scad, Selar crumenophthalmus (Carangidae), in La Réunion Island waters (south-western Indian Ocean). Cybium 24 (2): 173-179.

Ruttenberg B.I., Hamilton S.L., Walsh S.M., Donovan M.K., Friedlander A., DeMartini E., Sala E., Sandin S.A. 2011. Predator-induced demographic shifts in coral reef fish assemblages. PLoS ONE 6 (6): e21062.

DOI: 10.1371 journal.pone.0021062

Stergiou K.I., Karpouzi V.S. 2001. Feeding habits and trophic levels of Mediterranean fish. Reviews in Fish Biology and Fisheries 11 (3): 217-254.

DOI: $10.1023 / \mathrm{A}: 1020556722822$

Trianni M. 2011. Biological characteristics of the spotcheek emperor, Lethrinus rubrioperculatus, in the Northern Mariana Islands. Pacific Science 65 (3): 345-363.

DOI: $10.2984 / 65.3 .345$

Zander C.D. 1982. Feeding ecology of littoral gobiid and blennioid fishes of the Banyuls area (Mediterranean Sea). 1. Main food and trophic dimension of niche and ecotope. Vie et Milieu 32 (1): 1-10.

Received: 1 June 2011

Accepted: 14 April 2012

Published electronically: 30 June 2011 